\title{
PENGARUH KINERJA KEUANGAN DAN ECONOMIC VALUE ADDED TERHADAP RETURN SAHAM PADA PERUSAHAAN FARMASI DI BURSA EFEK INDONESIA
}

\author{
${ }^{1}$ Awaluddin ${ }^{1},{ }^{2}$ Shofwan Andri, ${ }^{3}$ Ramadona Simbolon \\ ${ }^{1,2,3}$ Universitas Islam Sumatera Utara \\ ${ }^{1}$ Awaluddinwal18@gmail.com, ${ }^{2}$ shofwanandri@gmail.com, ${ }^{3}$ ramadona.simbolon@fe.uisu.ac.id
}

\begin{abstract}
The purpose of this study is to prove the relationship between return on assets and economic value added with stock returns in pharmaceutical sector companies listed on the Indonesia Stock Exchange, from 2017 to 2019. Sampling was carried out by purposive sampling, and there were 6 companies used as samples. as research samples from 10 companies. The source of data in this study is secondary data obtained from the Indonesia Stock Exchange. Data were analyzed using multiple linear regression. The results of this study provide evidence that individually, return on assets has a positive and significant effect on stock returns, and economic value added does not have a significant effect on stock returns. Meanwhile, simultaneously return on assets and economic value added have a positive and significant effect on stock returns.
\end{abstract}

Keywords : Return On Asset, Economic Value Added, Return Saham

ABSTRAK : Tujuan penelitian ini yaitu untuk membuktikan keterkaitan antara return on asset dan economic value added dengan return saham pada perusahaan sektor farmasi yang tercatat di Bursa Efek Indonesia, pada tahun 2017 sampai dengan 2019. Penarikan sampel dilakukan dengan cara purpossive sampling, dan terdapat 6 perusahaan yang dijadikan sebagai sampel penelitian dari 10 perusahaan. Sumber data pada penelitian ini yaitu data sekunder yang didapatkan dari Bursa Efek Indonesia. Data dianalisis dengan memakai regresi linier berganda. Hasil penelitian ini memaparkan bukti bahwa secara induvidual return on asset memiliki pengaruh positif serta signifikan dengan return saham, dan economic value added tidak memiliki pengaruh yang signifikan dengan return saham. Sedangkan secara bersamaan return on asset dan economic value added memiliki pengaruh positif serta signifikan dengan return saham.

Kata Kunci : Return On Asset, Economic Value Added, Return Saham.

\section{Pendahuluan}

Pada umumnya, semua perusahaan yang melaksanakan usahanya baik pada bidang jasa, perindustrian dan perdagangan memiliki tujuan yang sama, yaitu memperoleh laba dalam jumlah yang besar, sehingga perusahaan mampu bertahan serta meningkatkan nilai pada perusahaan. tujuan tersebut salah satunya dilakukan guna meningkatkan kesejahteraan dan kekayaan dari setiap pemegang saham atau sering disebut dengan para investor.

Pasar modal yaitu sebuah tempat yang dapat mempertemukan kedua belah pihak yang melakukan transaksi saham, sesuai dengan aturan yang telah ditetapkan. Dari sudut pandang perekonomian, pasar modal juga mempunyai fungsi sebagai mobilitas dana dengan bagi pemerintahan. Hal ini dikarenakan dengan adanya pasar modal, pemerintahan dapat mengalokasikan dananya kepada masyarakat melalui berbagai jenis sektor yang potensial.

Return saham menjadi tujuan yang paling utama bagi para investor untuk melakukan investasi, guna memperoleh profit dari hasil investasi tersebut. Para investor akan dapat mendapatkan hasil dari investasi yang dapat berupa dividen dan juga capital again. Return saham yaitu tingkat pengembalian atas penanaman modal, yang dinilai sebagai keuntungan ataupun kerugian yang akan didapatkan oleh para investor. Tingkat pengembalian juga dapat dimanfaatkan sebagai alat untuk menilai keberhasilan perusahaan dalam mendapatkan laba dari penanaman modal 
yang meliputi return realisasi dan return ekspetasi (Gumanti, 2011).

Salah satu cara untuk mengamati kondisi finansial yaitu economic value added, yang merupakan hasil estimasi dari profit yang sebetulnya pada waktu tertentu. Penggunaan yang dilakukan terhadap economic value added, dapat membuat perusahaan lebih mengutamakan minatnya terhadap nilai perusahaan. Jika hasil pada economic value added mengalami kenaikan, maka terdapat nilai tambah yang diciptakan pihak, akan sangat berpengaruh terhadap harga saham, sebagai cerminan dari return saham yang akan diperoleh.

Faktor lainnya yang juga harus diperhatikan oleh para investor yaitu return on asset, yang merupakan suatu pengukuran terhadap besar atau kecilnya kemampuan dalam mendapatkan profit dari keseluruhan aktiva yang telah digunakan. Setiap perusahaan juga akan selalu berusaha untuk meningkatkan hasil pada return on asset, guna kelangsungan hidupnya. Semakin besar hasil return on asset, maka perusahaan juga akan semakin baik untuk memanfaatkan asetnya dalam memperoleh laba (Arista, 2012).

\section{Landasan Teori}

\subsection{Return Saham}

Menurut (Gumanti, 2011) return saham yaitu penghasilan atas penanaman modal yang telah ditinjau sebagai untung dan rugi yang akan didapatkan oleh para investor pada waktu yang telah ditentukan. Return saham juga dimanfaatkan sebagai peninjauan kesuksesan perusahaan, sehingga mampu memberikan gambaran terhadap nilai perusahaan. Hal ini dikarenakan apabila perusahaan mendapatkan hasil yang meningkat, maka saham tersebut akan digemari para investor yang ingin menanamkan modalnya. Perhitungan pada return saham dapat dilakukan dengan rumus berikut ini :

$$
\text { Return saham }=\frac{p^{t}-p^{t-1}}{p^{t-1}}
$$

\subsection{Return On Assets}

Menurut (Sirait, 2017) return on asset yaitu pengukuran yang dapat menggambarkan kemampuan perusahaan untuk mendapatkan profit atas sumber daya yang telah tersedia. Sedangkan menurut (Ikhwal, 2016) return on asset yaitu kondisi keuangan yang bertujuan untuk mengamati kemampuan dalam mendapatkan profit, dengan memanfaatkan keseluruhan aktiva yang telah tersedia dan setelah berbagai biaya modal dikeluarkan dari analisis. Perhitungan pada return on asset dapat dilakukan dengan rumus berikut ini :

$$
=\frac{\begin{array}{c}
\text { Return On Assets } \\
\text { Laba Bersih Setelah Pajak }
\end{array}}{\text { Total Aktiva }} \times 100 \%
$$

\subsection{Economic Value Added}

Economic value added yaitu sistem manajemen keuangan yang digunakan untuk mengamati profit dari segi ekonomi, yang mengatakan bahwa kesuksesan itu tercipta, apabila perusahaan tersebut mampu membiayai kegiatan operasinal dan modal pada perusahaan secara keseluruhan. Economic value added juga membuktikan skala yang benar, mengenai besar dan kecilnya kemampuan perusahaan yang telah memberikan dana tambahan terhadap nilai pemegang saham. Apabila manajemen dapat fokus terhadap economic value added, maka hal tersebut dapat membantu untuk memastikan, bahwa manajemen perusahaan dapat melaksanakan aktivitas operasionalnya secara konsisten, untuk memaksimumkan kekayaan bagi pemegang saham. Perhitungan pada economic value added dilakukan dengan menggunakan rumus berikut ini :

$$
\text { EVA = Laba Tahun Berjalan }- \text { Capital }
$$

\section{Metode Penelitian \\ 3.1. Populasi}

Menurut (Sugiyono, 2016) populasi adalah wilayah yang meliputi atas objek yang memiliki karakteristik yang ditentukan agar dapat dipahami, dan diambil atau ditarik kesimpulannya. Populasinya yaitu sebanyak 10 perusahaan farmasi yang listing di Bursa Efek Indonesia, pada tahun 2017 sampai 2019, dan terdapat perusahaan yang memenuhi ukuran atau memberikan faktor eksplorasi total dan memenuhi waktu tahun investigasi, yang dapat dijadikan sebagai contoh pada penelitian ini.

\subsection{Teknik Analisis Data}

Sumber datanya adalah data sekunder, yang merupakan sebuah informasi berupa data, dan kemudia dikumpulkan dari berbagai sumber yang tersedia. Data sekunder juga merupakan suatu dokumentasi, publikasi, tinjauan pustaka, analisis industri, situs web, internet dan lainnya. 
Teknik analisis datanya yaitu pengujian berganda dan pengujian hipotesis. deskriptif, pengujian asumsi dasar, regresi linier

\section{Hasil Penelitian}

\subsection{Analisis Statistik Deskriptif}

Tabel 1. Pengujian Deskriptif

Descriptive Statistics

\begin{tabular}{|l|l|r|r|r|r|}
\hline & $\mathrm{N}$ & \multicolumn{1}{|c|}{ Minimum } & Maximum & \multicolumn{1}{c|}{ Mean } & Std. Deviation \\
\hline ROA & 18 &, 001 &, 121 &, 06606 &, 031381 \\
EVA & 18 & 16740378288 & 8542745841 & 14862587637,6 & 72471120317,71 \\
& & 2 & 9 & 7 & 9 \\
Return Saham & 18 &,- 519 &, 160 &,- 08489 &, 190066 \\
$\begin{array}{l}\text { Valid N } \\
\text { (listwise) }\end{array}$ & 18 & & & & \\
\hline
\end{tabular}

Dari hasil pada data output di atas, maka diketahui bahwa :

a. Return On Asset punya nilai minimum dengan jumlah 0,001 , nilai maksimum dengan jumlah 0,121 , nilai mean dengan jumlah 0,06606 , dan standar deviasi dengan jumlah 0,031381 .

b. Economic Value Added punya nilai minimum dengan jumlah -167403782882, nilai maksimum dengan jumlah 85427458419 , nilai mean dengan jumlah 14862587637,67, dan standar deviasi dengan jumlah 72471120317,719 .

c. Return Saham, punya nilai minimum dengan jumlah $-0,519$, nilai maksimum dengan jumlah 0,160 , nilai mean dengan jumlah 0,08489 , dan standar deviasi dengan jumlah 0,190066 .

\subsection{Pengujian Asumsi Klasik}

\subsubsection{Uji Normalitas}

Tabel 2. Asumsi Normalitas

One-Sample Kolmogorov-Smirnov Test

\begin{tabular}{|c|c|c|}
\hline & & $\begin{array}{c}\text { Unstandardize } \\
\text { d Residual }\end{array}$ \\
\hline \multirow[t]{2}{*}{$\overline{\mathrm{N}}$} & & 18 \\
\hline & Mean & 0E-7 \\
\hline Normal Parameters ${ }^{\mathrm{a}, \mathrm{b}}$ & $\begin{array}{l}\text { Std. } \\
\text { Deviation }\end{array}$ & , 15360240 \\
\hline \multirow{3}{*}{$\begin{array}{l}\text { Most Extreme } \\
\text { Differences }\end{array}$} & Absolute & ,219 \\
\hline & Positive &, 103 \\
\hline & Negative &,- 219 \\
\hline Kolmogorov-Smirnov Z & & ,928 \\
\hline Asymp. Sig. (2-tailed) & & ,355 \\
\hline
\end{tabular}

Dari analisis terhadap data output di atas, membuktikan bahwa pada nilai asymptotic significance yaitu sebesar 0,355. Dengan dasar penentuan keputusan, maka 0,355 >0,05. Dari hasil pengujian SPSS (Statistical Product And Service Solutions), dapat disebutkan bahwa data mengikuti distribusi normal. 


\subsubsection{Uji Multikolinieritas}

Tabel 3. Pengujian Multikolinieritas

\begin{tabular}{|c|c|c|c|c|c|c|c|}
\hline \multirow{3}{*}{ Model } & \multicolumn{4}{|c|}{ Coefficients $^{\mathrm{a}}$} & \multirow{3}{*}{ Sig. } & & \\
\hline & \multicolumn{2}{|c|}{$\begin{array}{l}\text { Unstandardized } \\
\text { Coefficients }\end{array}$} & \multirow{2}{*}{$\begin{array}{c}\begin{array}{c}\text { Standardize } \\
\mathrm{d} \\
\text { Coefficients }\end{array} \\
\text { Beta }\end{array}$} & \multirow[t]{2}{*}{$\mathrm{t}$} & & \multicolumn{2}{|c|}{$\begin{array}{l}\text { Collinearity } \\
\text { Statistics }\end{array}$} \\
\hline & $\mathrm{B}$ & $\begin{array}{l}\text { Std. } \\
\text { Error }\end{array}$ & & & & $\begin{array}{c}\text { Toleranc } \\
\mathrm{e}\end{array}$ & VIF \\
\hline (Constant) &,- 310 & ,093 & & 3,329 & ,005 & & \\
\hline ROA & 3,358 & 1,315 & ,554 & 2,552 & ,022 & ,923 & 1,083 \\
\hline EVA & 2,563 & ,000 & 098, & ,450 & ,659 & 923 & 1,083 \\
\hline
\end{tabular}

a. Dependent Variable: Return Saham Sumber : Data SPSS, 2021

Dari analisis terhadap hasil output di atas, membuktikan bahwa nilai tolerance dari setiap variabel bebas, tidak menunjukkan hasil yang berkurang dari 0,10. Sedangkan perhitungan pada variance inflation factor dari setiap variabel bebas, juga tidak menunjukkan hasil yang berkurang dari 10,00. Maka disebutkan bahwa, tidak ada gejala multikolinieritas pada penelitian ini.

\subsubsection{Uji Heterokedastisitas}

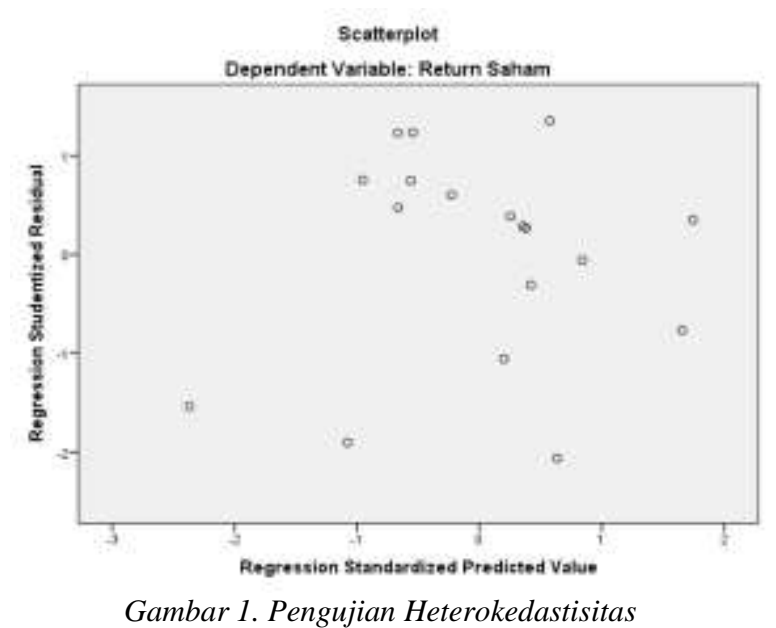

Dari analisis terhadap data output dalam bentuk grafik di atas, dapat membuktikan bahwa titik data telah tersebar secara acak, tidak terbentuk seperti pola yang bergelombang serta pola tertentu. Maka dinyatakan, tidak ada gejala heterokedastisitas pada penelitian ini.

\subsubsection{Uji Autokorelasi}

Tabel 4. Pengujian Autokorelasi

\begin{tabular}{|c|c|c|c|c|c|c|}
\hline $\mathrm{N}$ & $\mathrm{dw}$ & $\mathrm{dl}$ & $\mathrm{du}$ & $4-\mathrm{dw}$ & $4-\mathrm{dl}$ & $4-\mathrm{du}$ \\
\hline 18 & 1,750 & 1,046 & 1,535 & 2,250 & 2,954 & 2,465 \\
\hline
\end{tabular}

Dari analisis terhadap perhitungan tersebut, maka dijelaskan bahwa penentuan yang pertama yaitu tidak terdapat gejala autokorelasi positif. Hal ini dikarenakan bahwa nilai pada $\mathrm{dl}<\mathrm{dw}>\mathrm{du}$. Sedangkan untuk kriteria yang kedua yaitu tidak terdapat gejala autokorelasi negatif. Hal ini dikarenakan bahwa nilai pada $(4-d w)>d u$. Maka disebutkan bahwa, model regresi sudah terbebas dari gejala autokorelasi. Dengan demikian, dapat dilanjutkan pada pengujian selanjutnya yaitu regresi linier berganda. 


\subsection{Analisis Regresi Linier Berganda}

Tabel 5. Regresi Linier Berganda

Coefficients $^{\mathrm{a}}$

\begin{tabular}{|c|c|c|c|c|c|}
\hline \multirow[t]{2}{*}{ Model } & \multicolumn{2}{|c|}{$\begin{array}{l}\text { Unstandardized } \\
\text { Coefficients }\end{array}$} & \multirow{2}{*}{$\begin{array}{c}\begin{array}{c}\text { Standardize } \\
\mathrm{d} \\
\text { Coefficients }\end{array} \\
\text { Beta }\end{array}$} & \multirow[t]{2}{*}{$\mathrm{t}$} & \multirow[t]{2}{*}{ Sig. } \\
\hline & B & $\begin{array}{l}\text { Std. } \\
\text { Error }\end{array}$ & & & \\
\hline (Constant) &,- 310 & ,093 & & $-3,329$ &, 005 \\
\hline ROA & 3,358 & 1,315 & ,554 & 2,552 & ,022 \\
\hline EVA & 2,563 & ,000 & ,098 & ,450 & 659, \\
\hline
\end{tabular}

a. Dependent Variable: Return Saham

Sumber : Data SPSS, 2021

Pada hasil analisis dari data output di atas, maka diperoleh suatu persamaan dibawah ini yaitu sebagai berikut :

$$
Y=-0,310+3,358\left(X_{1}\right)+2,563\left(X_{2}\right)+e
$$

Dilihat dari persamaan regresi di atas, maka dinyatakan hasil sebagai berikut :

a. Nilai Konstanta dapat diprediksi yaitu sebesar -0,310. Artinya jika keseluruhan pada variabel bebas dianggap konstan, maka dapat diprediksi bahwa Return Saham menjadi berkurang sebesar -0,310.

b. Nilai Koefisien (Return On Asset) yaitu sebesar 3,358. Artinya jika terjadi peningkatan pada Return On Asset sebesar 1 satuan, maka Return Saham menjadi naik sebesar 3,358 satuan.

c. Nilai Koefisien (Economic Value Added) yaitu sebesar 2,563. Artinya jika terjadi peningkatan pada Economic Value Added sebesar 1 satuan, maka Return Saham menjadi naik sebesar 2,563 satuan.

\subsection{Pengujian Hipotesis \\ 4.4.1. Uji Parsial (Uji t)}

Pada hasil olahan data yang telah dilaksanakan, maka akan dibuktikan pengaruh atau keterkaitan antara variabel bebas dan terikat secara induvidual, yang ditampilkan pada tabel dibawah ini :

Tabel 6. Hasil Uji Signifikansi Parsial (Uji t) Coefficients $^{\mathrm{a}}$

\begin{tabular}{|c|c|c|c|c|c|}
\hline \multirow[t]{2}{*}{ Model } & \multicolumn{2}{|c|}{$\begin{array}{l}\text { Unstandardized } \\
\text { Coefficients }\end{array}$} & \multirow{2}{*}{\begin{tabular}{|c}
$\begin{array}{c}\text { Standardize } \\
\mathrm{d} \\
\text { Coefficients }\end{array}$ \\
Beta
\end{tabular}} & \multirow[t]{2}{*}{$\overline{\mathrm{T}}$} & \multirow[t]{2}{*}{ Sig. } \\
\hline & B & $\begin{array}{c}\text { Std. } \\
\text { Error }\end{array}$ & & & \\
\hline (Constant) & $\overline{-, 310}$ & ,093 & & $-3,329$ & ,005 \\
\hline ROA & 3,358 & 1,315 & ,554 & 2,552 & 022 \\
\hline EVA & 2,563 & ,000, & ,098, & 450, & 659 \\
\hline
\end{tabular}

a. Dependent Variable: Return Saham

Sumber : Data SPSS, 2021

Dari hasil analisis terhadap data output di atas, maka dapat diambil ataupun ditarik suatu kesimpulan yaitu :

\section{$\mathrm{H}_{1}$ : Return On Asset berpengaruh positif dan signifikan terhadap Return Saham}

Return On Asset mempunyai nilai signifikansi dengan jumlah $0,022<0,05$, dan nilai $\mathrm{t}_{\text {hitung }}$ dengan jumlah 2,522 $>2,144$ ( $\left.\mathrm{t}_{\text {tabel }}\right)$. Dalam hal ini, dikatakan bahwa Return On Asset mempunyai pengaruh positif serta signifikan dengan Return Saham. Maka $\mathrm{H}_{1}$ diterima, yang menyatakan Return On Asset 
mempunyai pengaruh secara signifikan dengan Return Saham.

\section{$\mathrm{H}_{2}$ : Economic Value Added tidak} berpengaruh dan signifikan terhadap Return Saham

Economic Value Added mempunyai nilai signifikansi dengan jumlah $0,659>0,05$, dan nilai $t_{\text {hitung }}$ dengan jumlah $0,450<2,144\left(t_{\text {tabel }}\right)$. Dalam hal ini, dikatakan bahwa Economic Value Added tidak mempunyai pengaruh yang signifikan dengan Return Saham. Maka $\mathrm{H}_{2}$ ditolak, yang menyebutkan Economic Value Added mempunyai pengaruh secara signifikan dengan Return Saham.

\subsubsection{Uji Simultan (Uji F)}

Pada hasil olahan data yang telah dilaksanakan, maka akan dibuktikan pengaruh atau keterkaitan antara variabel bebas dan terikat secara bersamaan, yang ditampilkan pada tabel dibawah ini :

Tabel 7. Hasil Uji Signifikansi Simultan (Uji F)

ANOVA $^{\mathrm{a}}$

\begin{tabular}{|rl|r|r|r|r|r|}
\hline \multicolumn{1}{|l|}{ Model } & \multicolumn{1}{|c|}{$\begin{array}{c}\text { Sum of } \\
\text { Squares }\end{array}$} & df & Mean Square & F & Sig. \\
\hline \multirow{2}{*}{1} & Regression &, 213 & 2 &, 107 & 3,984 &, $041^{\mathrm{b}}$ \\
& Residual &, 401 & 15 &, 027 & & \\
& Total &, 614 & 17 & & & \\
\hline
\end{tabular}

a. Dependent Variable: Return Saham

b. Predictors: (Constant), EVA, ROA

Sumber : Data SPSS, 2021

Dari hasil analisis terhadap data output di atas, maka dapat diambil kesimpulan bahwa variabel independen yang meliputi Return On Asset dan Economic Value Added mempunyai nilai signifikansi dengan jumlah 0,041 $<0,05$, dan nilai $t_{\text {hitung }}$ dengan jumlah 3,984 $<3,63$ $\left(\mathrm{t}_{\text {tabel }}\right)$. Maka $\mathrm{H}_{\mathrm{a}}$ diterima dab $\mathrm{H}_{\mathrm{o}}$ ditolak, dan juga disimpulkan bahwa Return On Asset dan Economic Value Added mempunyai pengaruh

positif serta signifikan dengan Return Saham secara bersamaan.

\subsection{Uji Determinasi $\left(\mathbf{R}^{2}\right)$}

Dari hasil olahan data yang telah dilaksanakan, maka dapat dibuktikan seberapa jauh kemampuan model dalam memberikan kontribusi pada variabel bebas, yang ditampilkan pada tabel dibawah ini :

Tabel 8. Hasil Koefisien Determinasi $\left(\mathrm{R}^{2}\right)$ Model Summary ${ }^{\mathrm{b}}$

\begin{tabular}{l|r|r|r|r|}
\hline Model & $\mathrm{R}$ & $\mathrm{R}$ Square & $\begin{array}{c}\text { Adjusted R } \\
\text { Square }\end{array}$ & $\begin{array}{c}\text { Std. Error of the } \\
\text { Estimate }\end{array}$ \\
\hline 1 &, $589^{\mathrm{a}}$ &, 347 &, 260 &, 163522 \\
\hline
\end{tabular}
a. Predictors: (Constant), EVA, ROA
bependent Variable: Return Saham

Dari hasil analisis terhadap data output di atas, maka dapat diperhatikan bahwa nilai determinasi (Adjusted $R$ Square) sebanyak 0,260 atau $26 \%$. Hal tersebut membuktikan bahwa Return On Asset dan juga Economic Value Added, hanya berkontribusi sebesar $26 \%$ terhadap pembagian Return Saham. Selebihnya yaitu $74 \%$ dipengaruhi variabel lainnya diluar model penelitian.

\section{Kesimpulan}

Penelitian ini mempunyai tujuan untuk mengamati keterkaitan antara Return On Asset dan Economic Value Added dengan Return Saham secara induvidual maupun bersamaan, pada perusahaan farmasi yang telah listing di Bursa Efek Indonesia, tahun 2017 sampai 2019. Dari hasil olahan data tersebut, maka diambil kesimpulan sebagai berikut :

a. Return On Asset mempunyai pengaruh yang positif serta signifikan dengan Return Saham secara individual pada perusahaan farmasi yang tercatat di Bursa Efek Indonesia, tahun 2017 sampai dengan 2019.

b. Economic Value Added tidak mempunyai pengaruh yang signifikan dengan Return 
Saham secara individual pada perusahaan farmasi yang tercatat di Bursa Efek Indonesia, tahun 2017 sampai dengan 2019.

c. Return On Asset dan Economic Value Added secara bersamaan mempunyai yang positif serta signifikan secara bersamaan dengan Return Saham pada perusahaan farmasi yang tercatat di Bursa Efek Indonesia, tahun 2017 sampai dengan 2019.

\section{DAFTAR PUSTAKA}

Arista dan Astohar. 2012. "Analisis Faktorfaktor yang Mempengaruhi Return Saham (Kasus pada Perusahaan Manufaktur yang Go Public di BEI periode tahun 20052009)". Jurnal Ilmu Manajemen dan Akuntansi Terapan, Vol. 3, No. 1.

Ghazali, Imam. 2013. "Aplikasi Analisis Multivariat Dengan Program Ibm Spss 21 Edisi 7". Semarang: Universitas Diponegoro.

Gumanti, (2011), "Pengaruh Informasi Laba, Arus Kas, dan Size Perusahaan terhadap Return Saham”. Jurnal Ilmiah Akuntansi Dan Humanika Jinah Vol.2 No.1 Sigaraja, Desember.

Ikhwal, (2016). "Determinan Risk Management Disclosure (RMD) Pada Perusahaan Perbankan Yang Terdaftar Di BEI'. Penelitian, Program Studi Akuntansi Universitas Negeri Semarang, Semarang.

Mangantar, A. A., Mangantar, M., \& Baramuli, D. N. (2020). "Pengaruh Return On Asset, Return On Equity dan Debt to Equity Ratio Terhadap Return Saham pada Subsektor Food and Beverage di Bursa Efek
Indonesia". Jurnal EMBA: Jurnal Riset Ekonomi, Manajemen, Bisnis dan Akuntansi, 8(1).

Mizan Enniyatul, (2018). "Pengaruh Rasio Profitabilitas da EVA terhadap Return Saha pada Perusahaan Otomotif di Bursa Efek Indonesia". Skripsi. Sekolah Tinggi Ilmu Ekonomi Indonesia, Banjarmasin.

Ramadhani, E., Putri, R. D., \& Istiqoma, V. A. (2018). "Effectiveness Of Information Services To Reduce Student Academic Procrastination In Working Thesis (Experiment Study On Student Of Guidance And Counselinguniversitas Pgri Palembang)". Jurnal Dosen Universitas PGRI Palembang.

Sekaran, Uma. 2011. "Research Methods For Business (Metode Penelitian Untuk Bisnis)". Jakarta: Salemba Empat.

Sirait Pirmatua, (2017), "Pengaruh Penilaian Kinerja dengan ROI dan EVA terhadap Return Saham pada Perusahaan yang Tergabung dalam Indeks LQ-45 di Bursa Efek Indonesia". Jurnal Akuntansi, Vol.2 No.1 Mei. Hal 70-92.

Sugiyono. (2016). "Metode Penelitian Kuantitatif Kualitataif dan Kombinasi (Mixed Methods)'”. Bandung: Alfabeta.

Tandelilin, Eduardus. 2010. "Portofolio dan Investasi: Teori dan Aplikasi. Edisi 1". Kanisius. Yogyakarta. Lind Marchal Wathen. 2014.

Wiagustini, Ni luh Putu. 2010. "Dasar-dasar Manajemen Keuangan". Denpasar. Udayana University Press. 